\section{Pest Damage to Pecan is Affected by Irrigation, Nitrogen Application, and Fruit Load}

\author{
Bruce W. Wood ${ }^{1}$ and Charles C. Reilly \\ U.S. Department of Agriculture, Agricultural Research Service, Southeastern \\ Fruit and Tree Nut Research Laboratory, Byron, GA 31008
}

Additional index words. Carya illinoinensis, integrated pest management, IPM, alternate bearing, crop thinning, water, aphids, mites, Melanocallis caryaefoliae, Eotetranychus hicoriae

\begin{abstract}
Orchard trees of pecan [Carya illinoinensis (Wangenh.) K. Koch] were subjected to combinations of cultural practices inducing differential physiological states so as to assess the potential for culture-related impact on damage to trees by key arthropod pests. Leaf $\mathrm{N}$ concentration, leaf water status, and crop load all affected foliar damage by black pecan aphids [BPA; Melanocallis caryaefoliae (Davis)] and pecan leaf scorch mite [PLSM; Eotetranychus hicoriae (McGregor)], as well as second-flush shoot growth. Damage to first-flush foliage in the late season by BPA generally diminished as leaf water status and leaf $\mathrm{N}$ concentration increased, but intensified with a reduction in crop load. Conversely, foliage damage by PLSM increased with elevated leaf water status and $\mathrm{N}$ concentration, but was unaffected by crop load. First- and second-order interactions for all combinations of cultural treatments conferring differential physiological states affected damage by pests and induction of second-flush shoot growth. Arthropod-induced defoliation on trees receiving highly favorable cultural practices-those producing high leaf $\mathrm{N}$, high leaf water availability, and low crop load-was greater than on trees receiving minimal or lesser cultural inputs. Thus, cultural practices influencing leaf water status, $\mathbf{N}$ status, or crop load potentially act and interact to produce both desirable and undesirable side-effects on damage incurred by certain arthropod pests and therefore merit consideration in efforts to develop improved integrated pest management strategies.
\end{abstract}

Effective pest management can be critical to profitable pecan husbandry. Such strategies are potentially influenced in unknown ways by cultural practices thought to enhance crop yields. Cultural practices can alter tree physiology, thus potentially influencing damage by pests. Damage to pecan foliage by black pecan aphids (BPA) and pecan leaf scorch mite (PLSM) is often serious, especially for alternate-bearing cultivars - where foliar health is closely linked to current and future yields (Sparks, 1981; Sparks and Brack, 1972; Worley, 1979a, 1979b). While effective chemical control strategies exist for BPA and PLSM (Ellis et al., 1994), control is increasingly difficult in certain well-managed orchards. Side-effects of cultural practices that affect tree physiology also may be involved, although these may reflect enhanced pesticide resistance.

The influence of cultural practices on pecan tree physiology and subsequent pest damage has received little study. Cultural inputs influencing tree physiology, and potentially pests, are irrigation, nitrogen, and crop load reduc-

\footnotetext{
Received for publication 26 Apr. 1999. Accepted for publication 5 Oct. 1999. The cost of publishing this paper was defrayed in part by the payment of page charges. Under postal regulations, this paper therefore must be hereby marked advertisement solely to indicate this fact.

'E-mail address: bwood@byronresearch.net
}

tion, which alter leaf water and $\mathrm{N}$ status, and the sink : source equilibrium of trees. Because reduced water availability can increase foliar $\mathrm{N}$ and sugar concentrations in late-season pecan foliage (Wood et al., 1995), damage by foliar-feeding pests might also be affected. Enhanced foliar N concentration can influence pest populations in agronomic crops, but effects are often contradictory (Jansson et al., 1986; Mittler, 1953; Salas et al., 1990; van Emden, 1973). Because arthropod reproduction requires nitrogenous compounds, and populations of BPA and PLSM naturally burgeon in late summer and early autumn when stresses induce leaf senescence, high foliar $\mathrm{N}$ concentrations may affect pest damage to foliage. Additionally, crop load influences foliar gas exchange, vigor, and senescence of pecan foliage (Wood, 1988); thus crop thinning (Reid et al., 1993; Smith and Gallott, 1990; Smith et al., 1993) may also affect pest damage. A better understanding of the interaction among tree physiology, cultural practices, and arthropod pests may influence integrated pest management (IPM) strategies. This study explores the relationship between the physiological status of pecan trees and damage incurred by BPA and PLSM.

\section{Materials and Methods}

Experimental design. All combinations of two leaf water and $\mathrm{N}$ concentrations, and two crop loads (i.e., sink : source equilibrium), were imposed to give eight different physiological states, a range of those likely to be exhibited by orchard trees in commercial operations.

The experimental plan was a three-factor factorial in a randomized complete-block design (10 blocks) with each experimental unit consisting of two trees $(n=160)$. The study was initiated in 1995 and terminated in 1997 . Test trees were $\approx 10$-year-old 'Cheyenne' spaced $\approx 9 \times 9 \mathrm{~m}$ on a Faceville sandy loam soil (siliceous thermic Typic Paleudult). Trees were managed prior to the study according to Georgia Extension Service recommendations for fertility and pests (Crocker, 1996; Ellis et al., 1994). Because of distance to adjacent orchards, the test orchard generally did not support economic levels of most pecan pests except for BPA and PLSM. Yellow aphids (Monellia caryella Fitch and Monelliopsis pecanis Bissell) were controlled by natural populations of lady beetles (Harmonia axyridis Pallas). Pesticide sprays were not required or applied, thus leaving seasonal BPA and PLSM populations to develop naturally. Plots were isolated by a single chisel plow cut $(\approx 30 \mathrm{~cm}$ deep) prior to the initiation of the study in February (only cutting an occasional root greater than $\approx 0.5 \mathrm{~cm}$ in diameter); these were not recut in succeeding years. Thus, trees were not stressed by chisel plow damage to roots during the study period. The test trees used in 1995 consisted only of "on" (i.e., heavy fruiting) trees.

Standard cultural practices were manipulated to provide different levels of leaf water status, leaf $\mathrm{N}$ concentration, and crop load.

Water management in orchards range from "non irrigated" to excessively "irrigated," thus resulting in considerable variability in tree water status. The levels utilized in this study were: 1) "low," where water was limited to natural precipitation $(\approx 140 \mathrm{~cm} /$ year; little or none in September and October and most during winter); and 2) "high," where trees received water via drip-irrigation to supplement natural precipitation. Water was applied according to a "rule-of-thumb system" for scheduling drip irrigation in Georgia, specifically using pan evaporation (Daniell, 1989). Application was based on average daily evaporation for the previous week with the drip system operating daily for different time intervals unless rainfall was $>1.3 \mathrm{~cm} /$ day and the system was turned off for $3 \mathrm{~d}$. Trees typically received $\approx 170 \mathrm{~L} /$ day of water via drip from September to October, but lesser amounts from May to August when rainfall was common. Midafternoon leaf conductance to water vapor was measured with a LI-COR 6400 Portable Photosynthetic System (LI-COR, Lincoln, Nebr.) to verify differential water status during the period of BPA and PLSM population development (i.e., August to October). High-water treatments typically displayed midafternoon stomatal conductance to water vapor $\approx 6-14$ times higher $(\approx 0.12-2.0$ $\left.\mathrm{mol} \cdot \mathrm{m}^{-2} \cdot \mathrm{s}^{-1}\right)$ than that of low-water treatments $\left(\approx 0.02-0.14 \mathrm{~mol} \cdot \mathrm{m}^{-2} \cdot \mathrm{s}^{-1}\right)$.

Different leaf $\mathrm{N}$ concentrations were achieved via soil application of $\mathrm{NH}_{4} \mathrm{NO}_{3}$. 
Treatments were: 1) "moderate" (i.e., $3.15 \mathrm{~kg}$ $\mathrm{NH}_{4} \mathrm{NO}_{3}$ per tree $=372 \mathrm{~kg} \cdot \mathrm{ha}^{-1}$ uniformly broadcast at budbreak over the $9 \times 9-\mathrm{m}$ area allocated to each tree); or 2) "high" (i.e., "moderate" rate plus $1.47 \mathrm{~kg}$ per tree per month uniformly broadcast as above from June to October). The "moderate" rate was based on previous-season leaf analyses and is the rate typically used in orchards in the southeastern United States to meet leaf N concentrations (O'Barr et al., 1989). Annual monitoring of leaf $\mathrm{N}$ concentration in late August from randomly selected trees indicated that $\mathrm{N}$ concentration, depending upon the test plot, ranged from $2.3 \%$ to $2.7 \%$ in the low-N treatment and from $2.8 \%$ to $3.1 \%$ in the high- $\mathrm{N}$ treatment. Verification of differential leaf $\mathrm{N}$ concentrations was based on middle leaflets sampled from the middle compound leaf of current season growth. Fifty leaflet pairs were sampled randomly $<4 \mathrm{~m}$ aboveground (O'Barr et al., 1989). Leaves were dried at $60^{\circ} \mathrm{C}$, ground, and analyzed for leaf $\mathrm{N}$ concentration by the Univ. of Georgia Plant and Soil Analysis Laboratory.

Differential crop load, or level of sink : source equilibrium, was achieved via fruit removal using mechanical tree shaker to produce either 1) "heavy crop load" trees ( high crop load typical of a strong alternate-bearing cultivar), or 2) "moderate crop load" [ $\approx 50 \%$ fruit removed via mechanical thinning at the end of the "water stage" of fruit development when the number of terminals producing fruit exceeded $\approx 50 \%$ (Reid et al., 1993; Smith and Gallott, 1990; Smith et al., 1993)]. The study was initiated when the test orchard was beginning an "on" year (1995). 'Cheyenne' is strongly biennial and nonthinned trees were in synchrony relative to their "on" vs. "off" years. Most trees that were thinned during the first year also required slight thinning during the second (1996) and third (1997) years of the study. Conversely, nonthinned trees produced little or no crop in 1996, thus we do not include data for 1996. Kernel yields (kg/tree) for trees thinned in 1995 averaged 3.8 in 1995, 2.9 in 1996, and 5.5 in 1997.

Response variables and analyses. Foliar damage by BPA was assessed by counting the total number of chlorotic blotches on the leaflets of the compound leaf occupying the midleaf position of the longest terminal. Terminals with missing leaflets at this leaf position were avoided. In mid-October, 10 terminal shoots $<3 \mathrm{~m}$ aboveground on the eastern side of each tree were randomly sampled from the trunk to the perimeter of the lower canopy, thus reflecting the zone most heavily damaged by BPAs.

Damage by PLSM was estimated in midOctober, after mite-induced leaflet scorch, as the percentage of leaflets remaining on the compound leaves of 10 terminal shoots sampled from the lower exterior of the eastern exposed canopy less than $\approx 3 \mathrm{~m}$ from the ground. Damage was verified via association of scorched leaflets with high numbers of mites (identified via microscopic examination). While factors other than mites can reduce leaflet numbers, BPA levels were not high enough to induce much leaflet drop except in the low, interior portions of the canopy, a region avoided by the PLSM sampling procedure. Water-stressrelated leaf loss did not occur in any treatment.

Treatments affected the frequency of second-flush shoots occurring from late July to late August. These were quantified in midOctober. All shoot flushes were counted on the western side of the tree and multiplied by two to derive the total number of flushes per tree.

Analyses of variance were performed using the SAS-GLM procedure (SAS Inst., Cary, N.C.). The absence of a significant year effect or interactions with measurement parameters facilitated analysis based on data pooled over 1995 and 1997.

\section{Results and Discussion}

Damage by black pecan aphids. Leaf N concentration, water availability, and crop load all influenced damage to foliage by BPAs (Table 1). Overall, high leaf $\mathrm{N}$ concentration or enhanced water availability reduced feeding damage to foliage by $30 \%$, whereas reduced crop load increased it by $60 \%$ (Table 2). The existence of first- and second-order interactions indicate that the actual influence of any one of these three physiological categories on BPA damage to foliage generally depended upon the other two. Interactions between $\mathrm{N}$ and crop load and irrigation and crop load were significant, but that between $\mathrm{N}$ and leaf water status was not (Table 1). A triple interaction was also significant. The greatest amount of damage occurred when trees had moderate leaf $\mathrm{N}$, low water status, and moderate crop loads (Fig. 1), whereas the least occurred when trees had high leaf N, high water status, and heavy crop load. The former trees approximate those receiving minimal cultural inputs in many orchards and were intermediate among the treatments in damage to foliage by BPAs (Fig. 1).

The effects of enhanced leaf $\mathrm{N}$ on aphid populations vary depending upon crop type and aphid species (Jansson and Smilowitz, 1986; Mittler, 1953; Salas et al., 1990; van Emden, 1973). These data on 'Cheyenne' pecan trees indicate that trees with relatively high leaf $\mathrm{N}(\approx 2.9 \%$ to $3.1 \%)$ suffered less foliar damage from BPAs than did those with moderate leaf $\mathrm{N}$ concentrations. Additionally, leaf water status appeared to be a key factor; enhanced leaf water status reduced cumulative feeding damage. The reason for less cumulative BPA damage to foliage of trees with heavy crop loads (i.e., greater sink : source disequilibrium) is unknown, but may be associated with higher photosynthetic activity in leaves because of greater sink demand generated by the developing crop; thus the onset of senescence was delayed (Wood, 1988). Because BPAs appear to reproduce better and to cause more injury to senescing than to nonsenescing foliage (Louis Tedders, personal communication), trees with fewer fruit may be more susceptible. Enhanced leaf water and N status tended to delay leaf senescence, hence potentially reducing BPA damage. While thinning to improve sink : source equilibrium in trees is beneficial from the standpoint of increasing kernel quality and return flowering (Smith and Gallott, 1990), an unexpected negative aspect observed in this study was that it also increased BPA damage.

Table 1. F ratios and associated probabilities $(P)$ for all main effects and interactions for damage to 'Cheyenne' pecan foliage by black pecan aphids (BPA) and pecan leaf scorch mites (PLSM) and for initiation of second-flush shoot growth.

\begin{tabular}{|c|c|c|c|c|c|c|}
\hline \multirow[b]{2}{*}{ Action or interaction } & \multicolumn{2}{|c|}{ BPA } & \multicolumn{2}{|c|}{ PLSM } & \multicolumn{2}{|c|}{ Second-flush growth } \\
\hline & $\mathrm{F}$ & $P$ & $\mathrm{~F}$ & $P$ & $\mathrm{~F}$ & $P$ \\
\hline Leaf nitrogen $(\mathrm{N})$ & 177.4 & 0.0001 & 119.0 & 0.0001 & 364.2 & 0.0001 \\
\hline Water availability (W) & 129.3 & 0.0001 & 173.0 & 0.0001 & 651.2 & 0.0001 \\
\hline Crop load (C) & 230.3 & 0.0001 & 10.3 & 0.0021 & 171.1 & 0.0001 \\
\hline \multicolumn{7}{|c|}{ Interaction } \\
\hline $\mathrm{N} \times \mathrm{W}$ & 0.4 & 0.5280 & 2.8 & 0.0001 & 114.9 & 0.0001 \\
\hline $\mathrm{N} \times \mathrm{C}$ & 6.9 & 0.0108 & 1.6 & 0.2041 & 14.9 & 0.0003 \\
\hline $\mathrm{W} \times \mathrm{C}$ & 4.5 & 0.0372 & 12.5 & 0.0008 & 2.9 & 0.0912 \\
\hline $\mathrm{N} \times \mathrm{W} \times \mathrm{C}$ & 25.7 & 0.0001 & 5.0 & 0.0282 & 2.2 & 0.1383 \\
\hline
\end{tabular}

Table 2. Main effects of leaf nitrogen concentration, water availability, and crop load on damage by black pecan aphid (BPA) and pecan leaf scorch mite (PLSM) and on second-flush shoot growth of 'Cheyenne' pecan.

\begin{tabular}{lccc}
\hline \hline Treatment & $\begin{array}{c}\text { BPA } \\
\text { (blotches per leaf) }\end{array}$ & $\begin{array}{c}\text { PLSM } \\
\text { (\% Leaflets remaining) }\end{array}$ & $\begin{array}{c}\text { Second-flush growth } \\
\text { (no. per tree) }\end{array}$ \\
\hline Moderate & 44 & Leaf nitrogen & 14 \\
High & $29^{* * *}$ & 59 & $38^{* * *}$ \\
& & $33^{* * *}$ & 18 \\
Low & 43 & Water availability & $42^{* * *}$ \\
High & $30^{* * *}$ & 59 & $32^{* * *}$ \\
& & & 34 \\
Moderate & 45 & Crop load & 52 \\
Heavy & $28^{* * *}$ & $39^{* * * *}$ & $18^{* * *}$
\end{tabular}

${ }^{* * *}$ Significantly different from moderate or low level of treatments at $P \leq 0.001$. 


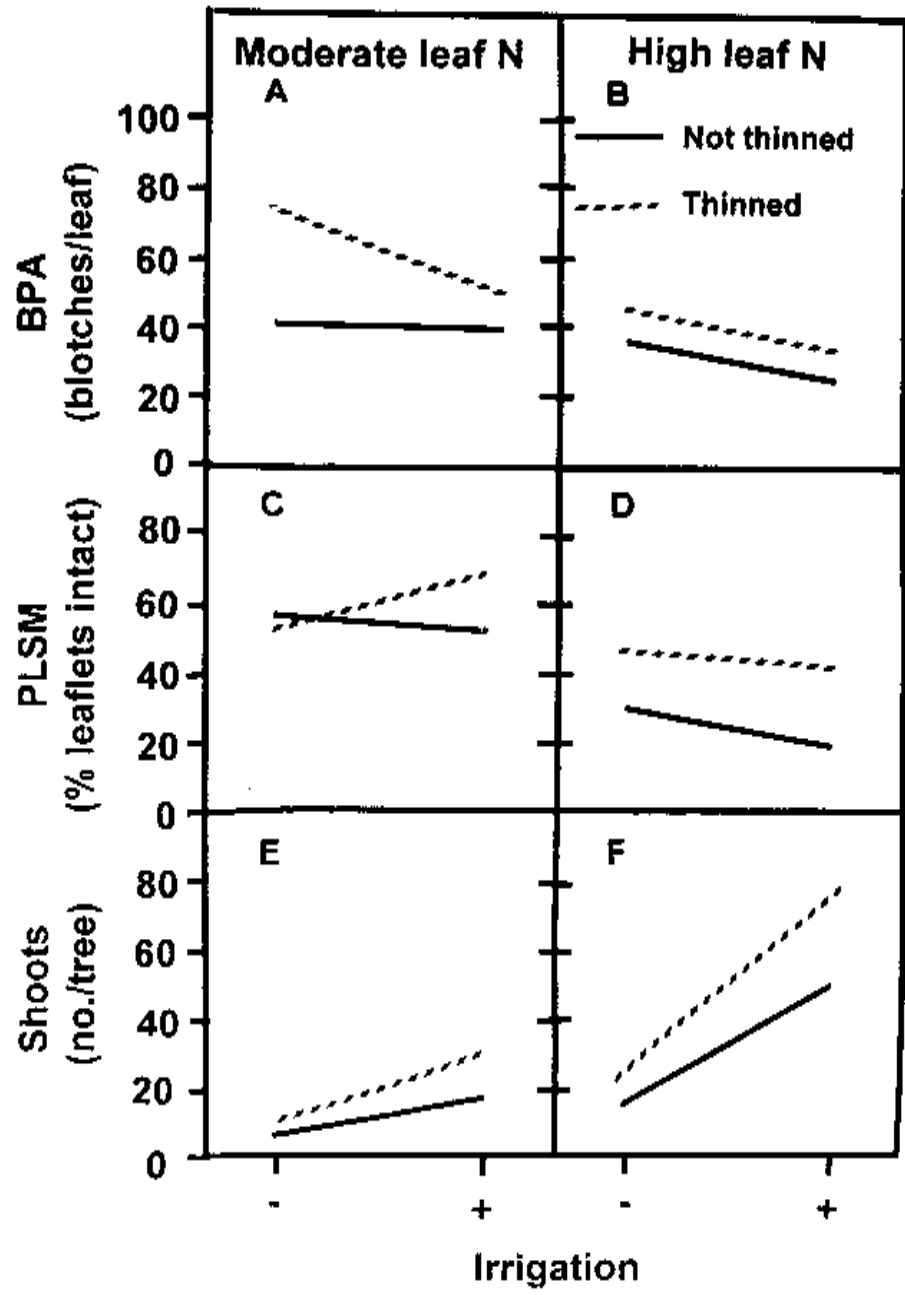

Fig. 1. Influence of crop load, leaf water status, and leaf nitrogen concentration on damage to 'Cheyenne' pecan foliage by black pecan aphids (BPA) and pecan leaf scorch mites (PLSM) and number of secondflush shoots per tree.

Damage by pecan leaf scorch mites. Damage to foliage by PLSM increased with elevated leaf $\mathrm{N}$ concentration or water status, but was reduced by thinning (Table 1). High leaf $\mathrm{N}$ concentration or enhanced water availability generally reduced the percentage of leaflets remaining on trees in October by about one-half (Table 2), and thinning increased the percentage by about one-third. Again, the leaf $\mathrm{N} \times$ water status $\times$ crop load interaction was significant $(P \leq 0.05)$. The greatest amount of damage occurred in trees with high leaf $\mathrm{N}$ concentration, high water status, and heavy crop load (i.e., greater disequilibrium between sink and source tissues) (Fig. 1), whereas the least damage occurred in trees with moderate leaf $\mathrm{N}$, high water status, and a moderate crop load.

Foliage of mature trees with enhanced leaf $\mathrm{N}$ concentration exhibited greater PLSM damage. This effect has been reported on potted pecan seedlings (Jackson and Hunter, 1983), but not on mature trees. Thus, the present study indicates that elevating leaf $\mathrm{N}$ concentrations of bearing trees may actually increase damage by PLSM.

Relatively high water availability, and therefore high leaf water status, increased foliar damage by PLSM. This is problematic in that
PLSM damage in orchards is typically most severe under the hot and dry conditions of early autumn (H.C. Ellis, personal communication). Dutcher et al. (1984) reported that PLSM populations on pecan were not influenced by irrigation, thus the effect of leaf water status on PLSM-induced damage to foliage may depend on air temperature.

In the present study, thinning of fruit to adjust crop load, or to alter the sink : source equilibrium, reduced damage by PLSM in most treatments. This raises questions as to whether foliage on thinned trees was less susceptible to damage or whether PLSM populations were lower. Thus the interaction of leaf senescence physiology and PLSMs merits investigation.

Second flush. The amount of second-flush shoot growth, generally perceived by orchard managers as favorable, was influenced by all three factors (Table 1). The average effect of elevating leaf $\mathrm{N}$ concentration and water status and reducing crop load was to increase the numbers of second-flush shoots per tree (Table $2)$. Interactions between leaf water status and crop load indicates that the influence of water status and crop load on second flush shoots depends on leaf $\mathrm{N}$ concentration (Table 2). Additionally, the effect of water status on second flush growth may also depend on crop load $(P=0.09)$. Triple interaction was not significant at $(P \leq 0.5)$, but a value of $P=0.14$ suggests that some interaction occurs. The greatest second-flush shoot growth occurred on thinned trees with high $\mathrm{N}$ status and high water availability (Fig. 1), and the least on control trees (low N, low water, and heavy crop load).

High leaf $\mathrm{N}$ concentration, high water, and reduced crop load enhanced second-flush shoot growth in late summer. Summer shoot growth may enhance future crop production by providing additional fruiting sites (Gossard, 1933). The increased frequency of second-flush shoots is consistent with increased vigor and may moderate alternate bearing because of good shoot development (Gossard, 1933).

This study indicates that the various aspects of tree physiology, as influenced by cultural inputs used in an effort to enhance nut yields, can alter damage by key arthropod pests. For example, foliage on trees receiving the best treatment (i.e., high water, high $\mathrm{N}$, and reduced crop load) was in a much worse state than that on trees not receiving these cultural inputs. Trees with enhanced leaf water status and reduced crop load, but low $\mathrm{N}$, had greatest foliar retention and health. Retention of foliage is generally considered critical in avoiding alternate bearing problems (Worley, 1979a, 1979b).

Our results are taken as evidence that the potential positive and negative side-effects of cultural practices thought to have no effect on pest problems merit greater consideration in efforts to develop improved IPM strategies for pecan.

\section{Literature Cited}

Crocker, T.F. 1996. Commercial pecan production in Georgia. Univ. of Georgia Coop. Ext. Serv. Bul. 609.

Daniell, J.D. 1989. Irrigation, p. 73-85. In: W.D. Goff, J.R. McVay, and W. S. Gazaway (eds.). Pecan production in the Southeast: A growers guide. Alabama Ext. Serv. ANR-459.

Dutcher, J.D., R.E. Worley, J.W. Daniell, R.B. Moss, and K.F. Harrison. 1984. Impact of six insecticide-based arthropod pest management strategies on pecan yield, quality, and return bloom under four irrigation/soil fertility regimes. Environ. Entomol. 13:1644-1653.

Ellis, H.C., P. Bertrand, T.F. Crocker, and S. Brown. 1994. Georgia pecan pest management guide. Georgia Coop. Ext. Serv. Bul. No. 841.

Gossard, A.C. 1933. The importance of maintaining vigorous terminal growth of pecan trees. Natl. Pecan Assn. Bul. 32:84-89.

Jackson, P.R. and P.E. Hunter. 1983. Effects of nitrogen fertilizer level on development and populations of the pecan leaf scorch mite (Acari: Tetraanchidae). J. Econ. Entomol. 76:432-435.

Jansson, R.K., G.C. Elliott, Z. Smilowitz, and R.H. Cole. 1986. Relationship between foliar nitrogen in three leaf zones of ten potato cultivars and population growth of the green peach aphid (Homoptera: Aphididae). Entomol. Soc. Pa. $36: 1-4$.

Jansson, R.K. and Z. Smilowitz. 1986. Influence of nitrogen on population parameters of insects: Abundance, population growth, and within-plant distribution of the green peach aphid, Myzus 
persicae (Homoptera: Aphididae). Environ. Entomol. 15:49-55.

Mittler, T.E. 1953. Amino acids in phloem sap and their excretion by aphids. Nature 172:207.

O’Barr, R.D., M. Smith, and G. Taylor. 1989. Pecan nutrition, p. 61-71. In: W.D. Goff, J.R. McVay, and W.S. Gazaway (eds.). Pecan production in the Southeast: A growers guide. Alabama Ext. Serv. ANR-459.

Reid W., S.M. Huslig, M.W. Smith, N.O. Manes, and J.M. Whitworth. 1993. Fruit-removal time influences return bloom of pecan. HortScience 28:800-802

Salas, M.L., L.J. Corcuera, and V.H. Argandona. 1990. Effect of potassium nitrate on gramine content and resistance of barley against the aphid Schizapis graminum. Phytochemistry 29:3789-3791.
Smith, M.W. and J.C. Gallott. 1990. Mechanical thinning of pecan fruit. HortScience 25:414-416.

Smith, M.W., W. Reid, B. Carroll, and B. Cheary. 1993. Mechanical fruit thinning influences fruit quality, yield, return fruit set, and cold injury of pecan. HortScience 28:1081-1084.

Sparks, D. 1981. Physiology-site, growth, flowering, fruiting, and nutrition, p. 211-239. In: R. Jaynes (ed.). Nut tree culture of North America. Northern Nut Growers Assn., Painesville, Ohio.

Sparks, D. and C.E. Brack. 1972. Return bloom and fruit set of pecan from leaf and fruit removal. HortScience 7:131-132.

van Emden, H.F. 1973. Aphid host plant relationships: Some recent studies, p. 54-64. In: A.D. Lowe (ed.). Perspectives in aphid biology. Entomol. Soc. New Zealand, Auckland Bul. No. 2.
Wood, B.W. 1988. Fruiting affects photosynthesis and senescence of pecan leaves. J. Amer. Soc. Hort. Sci. 113:432-436.

Wood, B.W. and C.C. Reilly. 1998. Susceptibility of pecan to black pecan aphids. HortScience 33:798-801.

Wood, B.W., C.C. Reilly, and W.L. Tedders. 1995 Relative susceptibility of pecan cultivars to fungal leaf scorch and its interaction with irrigation. HortScience 30:83-85.

Worley, R.E. 1979a. Fall defoliation date and seasonal carbohydrate concentration of pecan wood tissue. J. Amer. Soc. Hort. Sci. 104:195199.

Worley, R.E. 1979b. Pecan yield, quality, nutlet set, and spring growth as a response to time of fall defoliation. J. Amer. Soc. Hort. Sci. 104:346351 